\title{
Mobile Learning Application Development for Improvement of English Listening Comprehension
}

\author{
In Rural Primary School Students of Grade 1, 2 and 3 of Pakistan
}

\author{
Zahida Parveen Laghari \\ Department of computer science \\ Isra University \\ Hyderabad, Pakistan
}

\author{
Hameedullah Kazi \\ Department of computer science \\ Isra University \\ Hyderabad, Pakistan
}

\author{
Muhammad Ali Nizamani \\ Department of computer science \\ Isra University \\ Hyderabad, Pakistan
}

\begin{abstract}
Trend towards English language learning has been increased because it is considered as Lingua franca i.e. language of communication for all. However students of Pakistan are behind in this pace, especially rural elementary students. In rural areas there is crucial need to get assistance in their own curriculum after school because mostly they do not find anyone to help at home. M-Learning (Mobile Learning) assists learning anywhere and anytime. This ubiquitous power of M-Learning helps in after school programs and education in rural areas. The aim of this study is to develop M-Learning application for improvement of English listening comprehension in rural primary school students. This study developed English learning application based on Listening Comprehension, which embeds English curriculum of Sindh Textbook board for grade 1, 2 and 3. This study took the form of an after-school program in a village in Pakistan. There were 45 students of grade 3 from rural primary school of Pakistan selected as participants. Since developed application is based on recognition and memorization of information, so that knowledge and comprehension level of cognitive domain from Bloom's taxonomy were selected for choosing the type of evaluation questions. On the basis of those question types, EGRA (Early Grade Reading Assessment) test is used for evaluation. This test was conducted on two experimental groups and one control group and the results of the groups were compared to one another. The results confirm that English Mlearning applications can become helpful tool for students who live in rural areas where they face problems in learning of their English curriculum, since their relatives are not capable to teach them as accordingly.
\end{abstract}

Keywords-Mobile Learning (M-Learning); Early Grade Reading Assessment (EGRA); English as Secondary Language (ESL); Automatic Speech Recognition (ASR); Personal Digital Assistance (PDA)

\section{INTRODUCTION}

English is a core curriculum which is taught to students from grade 1 in Pakistan. In spite of that it is not getting prosperity in primary level rural schools of Pakistan [1]. Rural students are unable to speak English because they are just paying attention to passing the examination instead of learning the language as a tool for communication. In rural areas of Pakistan [2] the failure ratio in the English language as compared to other subjects is very high and unfavorable. English curriculum is not implemented properly in rural primary level schools due to general challenges of external factors (family background, economic condition, mother tongue, un-trained teachers, traditional atmosphere of village, exam oriented learning and copying in exams) in education system [3]-[5]. Thus rural students are not competent compared to urban students in English language [6], because their families work in agriculture and they focus on earning instead of learning.

At the same time, M-Learning is considered as inspiring approach of twenty first century as it comes with new trend of learning [7], where learner's Smartphone is embedded with M-learning applications. Learning ESL (English as Secondary Language) [8] through a mobile device can provide such flexibility in the improvement of education and it provides opportunity to educate every one and constraint of time slots and locations are detached. M-learning has great impact on ESL learning [9] particularly for those, who live in rural areas. Learning applications integrated on mobile devices, offers benefits to students of all levels and ages. Students have been promoted by mobile learning applications both in and out of teaching space [10]. These Applications are based on famous theories of language learning to improve ESL [11], so the students have opportunity to learn on demand.

Listening acts a significant role in everyday communication and educational process. It has been investigated that second language acquirement must require listening comprehension, quality of listener and listening comprehension purely influenced by listener variables (vocabulary knowledge, meta cognition, working memory and auditory discrimination). Listening comprehension mode enables learner [12] to gain English language by listening well. For ESL learning there should be huge amount of listening provided to listener and teacher must encourage students to engage in concentrated listening in class. This method enables students [13] to understand the meaning, pronunciation, intonation and the change in language flow. For the improvement of English Curriculum's Comprehension there is need to provide audio input to students for achieving Language learning [14], because listening is basic language skill in language learning. Listening comprehension can influence on listeners' [15] cognitive process and enhance his/her efficiency, utility and success in English learning achievement. English curriculum can be proficient when it could be taught as language and learning of language needs colossal introduction of auditory [16]. Therefore it can be 
believed that similar outcomes can be replicated with $\mathrm{M}$ learning application that are based on listening comprehension methodology which targets to rural primary students and the application embeds their own English curriculum.

\section{RELATED WORK}

There are numerous M-learning applications developed for mobile devices which help in learning ESL, some of them are discussed below.

1) Speaking English 60 Junoir: It was based on ASR (Automatic Speech Recognition) and it empowers students to practice English with immediate result from application. It includes 60 key expression extracted from the Korean national curriculum, consists of two parts Lesson and Takes. The students can practice oraly whatever content shown to them in Lesson session. They used application for 2 weeks in and out of the classroom. They selected 302 students from five schools. It was found that $54 \%$ students agreed upon application convenience and $47 \%$ agreed upon application was interesting and learning [17].

2) Mobile Game-Based Learning Application: It was designed to enhance students' listening and speaking skills. It was based on PHP, MYSQL and Apache sever. Client platform was run on Android and sever run on windows 2003. Evaluation based on three week study. Four classes of 30 minutes were conducted, two groups of 20 female students were made and named as control-group and experimental group. Results showed that students who learned from mobile-system have more improvement than who have learnt through traditional method [18].

3) Mobile Learning System: It was designed for assisting the listening and speaking skills. This system includes six learning initiatives (Vocabulary repetition, Role-play, You speak, then I speak, Brainstorming-photo, words and photo, voice and words) which were embedded on PDA (Personal Digital Assistance). Total 33 Students of $5^{\text {th }}$ grade of elementary school (10 or 11 years old) for one semester were selected. Pre-test and Post-test result showed that students had positive perception towards the system [19].

4) English Pronunciation App: It was based on pronunciation of words. This app was designed to improve pronunciation of English in college students of Indonesia. It was based on Android platform; it includes vowels, diaphones and consonant tests. After welcome screen the user has to choose which section he wants to learn (vowels/consonants). Words are shown with options of pronunciation, then learner has to decide which one is best pronunciation. There were 100 respondents who used this application. Majority of students became able to know correct pronunciations of mostly mispronounced words [20].

5) Voice Recognition Technology: It embedded on android and based on voice recognition method. Through this feature students can become capable to practice the pronunciation of English words. It was designed for professionals, based on business English. Questions were presented to learner and learner has to answer in his/her voice then learners' voice goes to Google Voice search. After complete test learner can check his/her mistakes. Questionnaire was distributed to 35 users and they got positive result towards application [21].

6) Video Caption Modes: They have investigated impact of various video caption modes (Full-caption, non-caption and target-word mod) on students. It was embedded on mobile phone. Students of $5^{\text {th }}$ grades were experimented for one month. Weekly test conducted to test students' English listening comprehension and vocabulary acquisition. Instructional videos related to lesson were displayed on PDA and after watching the video they immediately took a test to evaluate their listening comprehension and vocabulary proficiency [10].

7) Grammar Clinic: It was a web-based mobile application, which was provided as supplementary tool to students. First of all Grammar Clinic displays sentences to user then user has to identify grammatical mistakes from given sentences and make corrections. After user had corrected the sentence, it will show result and short grammar handbook according to that exercise. The types of errors included verb use, article use, noun use, word choice, adverb use, word order, conjunction use, preposition use and unambiguous expression. Intermediate level students were selected as experimental group; they were allowed to use Grammar Clinic three days a week for 16-weeks. Their score was 8.82 out of 10 for higher error correction and 7.29 out of 10 for low error correction. It had positive impact on students' grammar comprehension by identifying and then correcting the errors [22].

8) Cellphone Game: It was based on listening comprehension, word recognition, sentence construction, and spelling for various levels. It Included local English needs, and was tested in after school settings. Rural students were selected for study, those having difficulty to access the school. Analyzed low-gain and high-gain students, satisfactory results were found between high-gain and low-gain students. Qualifying test scores of high-gain were 49/50 and scores of low-gain were 46.5/50 [6].

9) Mobile Learning Technology: ESL material placed on server and was accessed by mobile device. It was based on Penguin introductory English grammar and exercise books. The course consists of 86 lessons and related exercises for teaching basic English language, ranging from is and are to verb tenses, countable nouns, and other aspects of grammar. Students completed three grammar tests during the study. Pretest scores were 15/20, Post-test were 17.7/20, and scores in the Retention-test were 18 , these scores were found after three tests [23].

Above discussed applications were developed for prosperity of English Language learning, however no existing M-Learning application for English Language have focused on elementary school students plus incorporating their own national curriculum and importantly applying listening comprehension strategy. M-Learning applications provide an 
opportunity to students to learn English; however the problem with existing applications is that they are based on general or business English rule. Therefore, these apps are mostly different from their own national English curriculum.

To achieve this goal there is need to develop mobile application that is based on listening comprehension method, incorporates students own English curriculum and specially designed for elementary students, so that they can learn English after school when they do not find anyone to help them.

\section{METHODOLOGY}

\section{A. Curriculum and Prototype Development}

The main focus of this study was to develop an English Mlearning application which embeds student's own curriculum. This helps students to learn their English curriculum on their own and increase their learning outcomes particularly in an English curriculum comprehension.

1) Curriculum Design: The English curriculum of Sindh Textbook board for grade 1, 2 and 3 was selected for this study. Its was selected in terms of listening comprehension, pronunciation, reading lessons and spellings. It was studied within the classroom theme, which readily related to participants. It also considered participants' competency and performance. Concretely, the curriculum includes:

a) Common world objects: Objects which are mostly studied in grade1 and 2.

b) Reading Text: Nine lessons were selected from grade 1, 2 and 3 for text reading.

c) Spellings of words: Spellings of words were selected alphabetically from grade 1, 2 and 3 .

d) Grammer Excersies: Excersies, particularly parts of speech were focused from grade 1 .

2) Prototype Development: This study developed a prototype based on above curriculum and it contained four sections i.e. Learn, Read, Spellings and Play as shown in Fig. 1.

a) Learn Section: This section includes different objects' (Alphabets, Numbers, Body Parts, Fruits, Colors, Shapes, Vehicles and Verbs) names with their image and pronunciation, so that students can become capable to pronounce these objects. By clicking play button and listening names of these objects their knowledge base for memory recall will increase. As a result, their cognitive ability will increase [24]. These all objects have been taken from curriculum of grade 1 and 2 of Sindh's Textbooks as shown in Fig. 2.

b) Read Section: This section contains lessons of grade 1, 2 and 3 of Sindh's Textbooks so that the students can become capable to remember their lesson by clicking word by word, after school or anywhere as shown in Fig. 3.

c) Spellings Section: This section contains spellings from A to Z alphabetical words of grade 1 so that the students can become capable to remember the spellings by clicking letter by letter as shown in Fig. 4. d) Play Section: This section contains prepositions and adjectives excerises from grade 3 books. It contained fill in the blanks excerises. By playing these exercises students become capable to learn about grammer rules as shown in Fig. 5.

\section{B. Participants}

The target users were students of rural primary schools of district Sanghar, Taluka Sinjhoro, Sindh, Pakistan. Several surveys were conducted to measure students learning abilities. The data was collected from total 45 students of grade 3 with their age ranging from 8-14 years, which were distributed in three groups, where one was Control Group and two were Experimental Groups. Further details of groups are given below:

a) Group 1 (Control Group): This group included 15 students of Nazar Ali Khan Nizamani Boys Primary School Taluka Sinjhoro District Sanghar. This school is located in village Nazar Ali Khan Nizamani, which is 26 kilometers away from Sanghar city. There were 4 boys and 11 girls (8-14 years old) and their mother tongue was Sirraiki.

b) Group 2 (Experimental Group 1): This group included 15 students of Abdul Karim Sirewal Boys Primary School Taluka Sinjhoro District Sanghar. This school is located in village Abdul Karim Sirewal, which is 10 kilomerters away from Sanghar city. There were 3 boys and 12 girls (8-14 years old) and their mother toungue was Balochi and Siraaiki.

c) Group 3 (Experimental Group 2): This group included 15 students of Darul-Elomia-Latifia Sanghar. This school is for religious studies, located in Sanghar City. There were 15 boys who were 8-14 years old. Majority of students never got chance to learn English language before, because they just had focused on Islamic studies and Holy Quran. Their aim of life was to become Hafiz-e Quran (The one who memorizes Holy quran). Even most of them thought that Islamic studies have superiority, so they just have to concentrate on Islamic studies.

\section{Teaching Method}

This study took form of after school program and each session lasted for two hours in afternoon. The after-school program took place from January 2016 to March 2016 and spanned sessions on 60 days in total (30 days per each group).

- Control group was taught with two hour regular English class for one month.

- Experimental groups were taught with one hour regular English class and for one hour they were given a tablet PC loaded with developed prototype as a supplementary tool.

\section{Research tools}

1) Bloom's Texanomy: It is a classification method to classify intellectual ability and behavior essential to learning. It was created by a psychologist Benjamin Bloom and his colleagues in 1956. It was established as a method of categorizing educational goals for student performance 
assessment [25]. It consists of three main domains of learning i.e. Cognitive, Affective and Psychomotor.

a) Cognitive Domain: This domain covers growth of intellectual ablities and recalling information form long term memory.

b) Affective Domain: This domain covers development of emotions, fellings and attitudes.

c) Psychomotor Domain: This domain covers development of manipulative behavouir or motor skills.

From above described domains the Cognitive Domain is mostly used to assess learning behavior of students. Since this research evaluates the learning outcome of elementary school students, the Cognitive Domain has been used in this research because this domain focuses on recognition, recall, memorizing and visualizing of learning/educational material. It analysis students initial learning or primary learning behavior.

2) Cognitive domain: The Cognitive domain includes knowledge and the growth of intellectual skills. This includes the recall/recognition of particular information, procedural patterns, and ideas that serve in the growth of intellectual skills and abilities There are six major types of cognitive domain as shown in Fig. 6 and Table. 1.

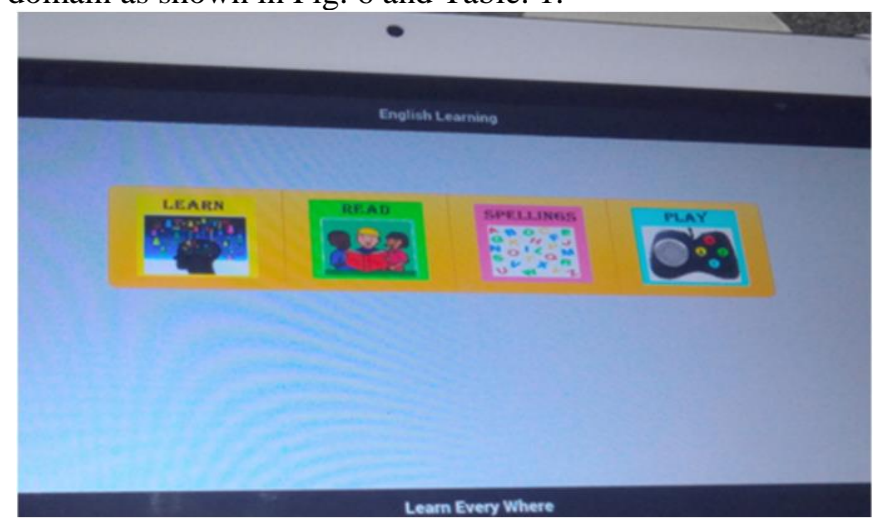

Fig. 1. User interface of prototype, it contianed four sections learn, read, spellings and play.

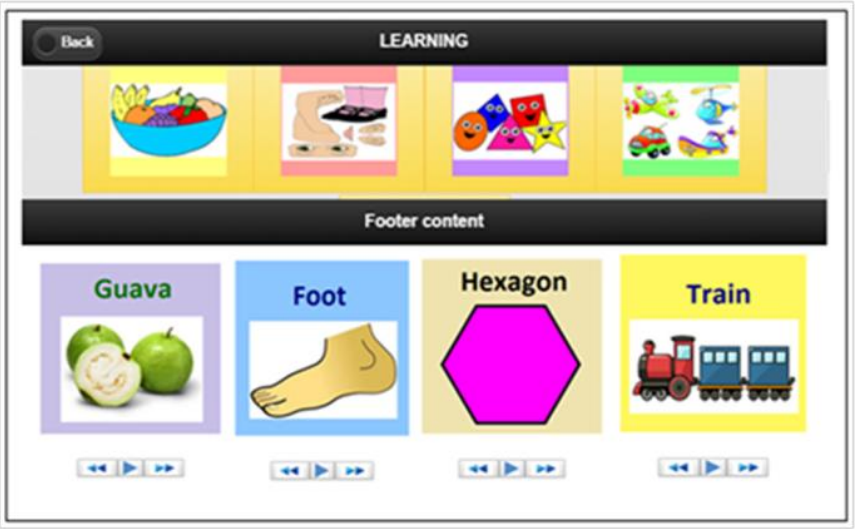

Fig. 2. Learning Section of prototype which contained above objects and clicking play button, students will become able to learn about pronounciation objects names.

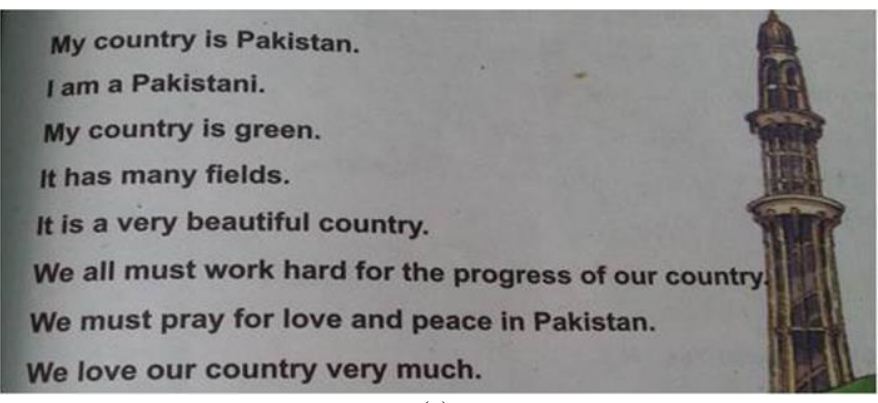

(a)

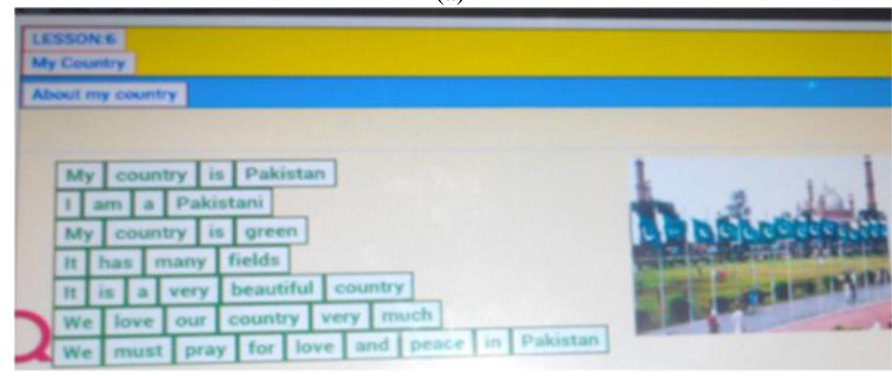

(b)

Fig. 3. Lesson of Sindh's Textbook embedded in reading section.

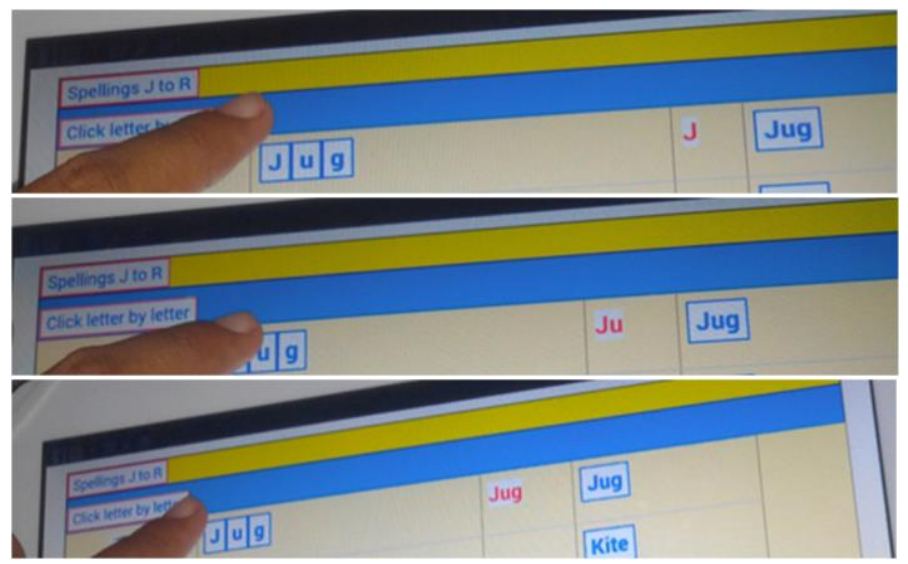

Fig. 4. Spellings section of prototype and its click event.

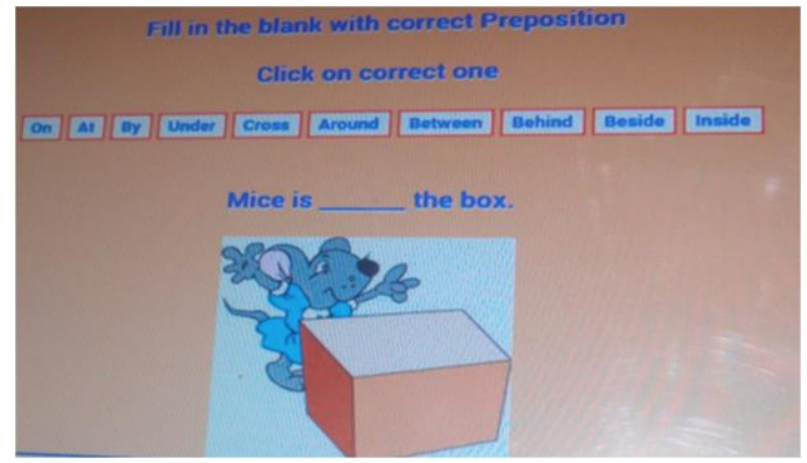

Fig. 5. Play section contains exercise of grade 3, by choosing right option student can fill the preposition into blank.

In this study knowledge and comprehension layers of Cognitive domains were selected to measure learning outcomes of elementary students of grade 1,2 and 3. On the basis of these layers question types of the EGRA test for their assessment are selected. 


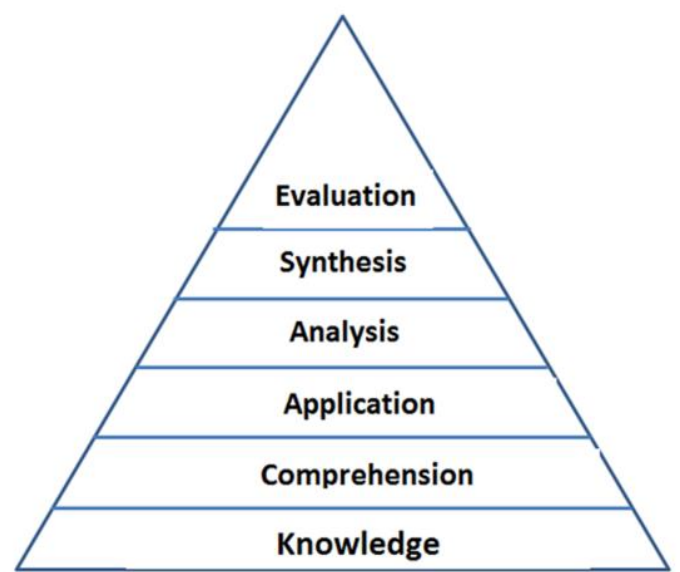

Fig. 6. Layers of cognitive domain of Bloom's Taxonomy.

TABLE I. COGNITIVE DOMAIN LAYERS

\begin{tabular}{|l|l|l|}
\hline \multirow{2}{*}{$\begin{array}{l}\text { Cognitive } \\
\text { Domain Layers }\end{array}$} & Explanation & Question Types \\
\cline { 2 - 3 } Knowledge & $\begin{array}{l}\text { Rescription } \\
\text { knowledge from long } \\
\text { term memory }\end{array}$ & $\begin{array}{l}\text { recall, sort, recite, } \\
\text { select, state, tell, find, } \\
\text { pick, group, identify, } \\
\text { indicate match, name }\end{array}$ \\
\hline Comprehension & $\begin{array}{l}\text { Making Sense of what } \\
\text { you have hear, read and } \\
\text { visualized }\end{array}$ & $\begin{array}{l}\text { comprehend, conclude, } \\
\text { contrast, illustrate, } \\
\text { outline, } \\
\text { demonstrate }\end{array}$ \\
\hline Application & $\begin{array}{l}\text { Use the gained } \\
\text { knowledge in new ways }\end{array}$ & $\begin{array}{l}\text { Apply, construct, } \\
\text { classify, develop, } \\
\text { organize, solve, test, } \\
\text { use, utilize }\end{array}$ \\
\hline Synthsis & $\begin{array}{l}\text { Breaking knowledge } \\
\text { into parts getting } \\
\text { meaning from those } \\
\text { parts }\end{array}$ & $\begin{array}{l}\text { analyze, assume, } \\
\text { breakdown, divide, } \\
\text { deduce, diagram, infer }\end{array}$ \\
\hline Evaluation & $\begin{array}{l}\text { Making judgment on } \\
\text { the basis of guideline }\end{array}$ & $\begin{array}{l}\text { rearrange, write, } \\
\text { reconstruct, revise, } \\
\text { suggest, what, } \\
\text { synthesize }\end{array}$ \\
\hline $\begin{array}{l}\text { reject/accept, referee, } \\
\text { select, settle, support, } \\
\text { umpire, weigh, which }\end{array}$ \\
\hline ways
\end{tabular}

3) EGRA: It is an individually managed oral assessment of foundation literacy abilities requiring about 15 minutes per child. It was developed by World Bank and USAID (United State Agency for International Development) to develop an instrument for assessing early grade reading. It is used by ministry to identify schools with particular needs and develop instructional approaches for improving foundation abilities. It has a group of subtasks; each with a specific purpose. The test modules are based on references made by an international board of testing experts and reading also include timed, 1minute assessments of different tasks [26]-[28].

Pre and post-test are designed on the basis of EGRA's seven tasks. These tasks are given below:

a) Task 1 Phonemic Awareness: In this Task students have to identify the word that starts with different sound in given set of words. b) Task 2 Letter Name Identification: In this task student has to call the names of set of 100 Upper and Lower case letters.

c) Task 3 Object Name Translation: In this task students have to translate given object names into English.

d) Task 4 Letter to Words Conversion: In this task students have to convert given letters into word.

e) Task 5 Word to spellings: In this task students have to tell spellings of given words.

f) Task 6 Reading Compirehension: In this task students have to read the given passage of text and after complition he/she has to answer the given question.

g) Task 7 Identification of Object names: In this task student has to first identify the objects then he/she has to tell the name of object in English.

\section{E. Experimental Procedure}

At the beginning of the learning activities, the students took the pre-test in order to record their pre-test score before using developed prototype.

Experimental procedure was started by taking pre-test from all students (15 mints per students) from each group (control group $\mathrm{N}=15$, experimental group $1 \mathrm{~N}=15$ and experimental group $2 \mathrm{~N}=15$ where $\mathrm{N}$ is the no. of participants), then treatment (developed prototype was given them as supplementary tool with traditional class of English) has been given for one month to experimental groups and control group was taught with traditional teaching method of English in class. Finally the study took post-test from students and calculated pre and post-test mean differences, as well as statistical significance $(p<0.001$, Mann-Whitney) of results were also considered. Fig. 7 presents a flow chart of the experimental procedure.

\section{F. Results}

The tests were made on the basis of EGRA's seven tasks and those tests were taken from all groups i-e one control group and two experimental groups. From results it was found that both experimental groups have higher mean difference values as compared to control group.

1) Comparsion of Pre and Post-Test Mean Differences:

First of all pre-test mean of each task in all groups were calculated and after one month post-test mean of each task in all groups was calculated. Then differences of pre and posttest mean were calculted and finally pre and post-test mean differences were campared among all groups. Group wise comparisons are given below.

a) Pre and Post-test Mean Results of Experimental Group 1: There were 15 students selected of grade 3 and evaluated all 7 tasks of EGRA among students and the pre and post evaluation means are shown in Table 2 and Fig. 8.

b) Pre and Post-test Mean Results of Experimental Group2: There were 15 selecteds selected of grade 3 and evaluated all 7 tasks of EGRA among students and the pre and post evaluation means are shown in Table 3 and Fig. 9. 


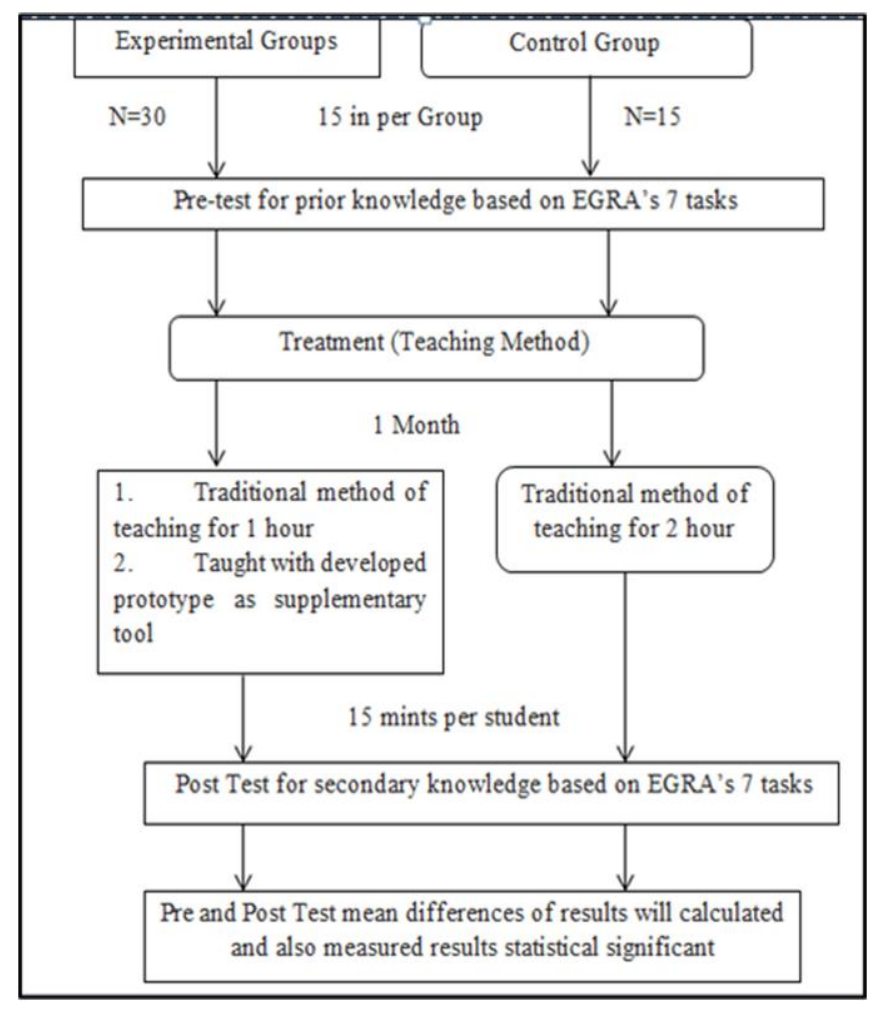

Fig. 7. Flow chart of the experimental procedure.

TABLE II. PRE ANd Post EVAluation MEAN OF EXPERIMENTAL GROUP 1 IN ALL 7 TASKS

\begin{tabular}{|c|c|c|c|c|c|c|c|}
\hline \multirow{2}{*}{$\begin{array}{l}\text { Mean of } \\
\text { Experimental } \\
\text { Group 1 }\end{array}$} & \multicolumn{7}{|c|}{ Tasks } \\
\hline & $\begin{array}{l}\text { Task } \\
1\end{array}$ & $\begin{array}{l}\text { Task } \\
2\end{array}$ & $\begin{array}{l}\text { Task } \\
3\end{array}$ & $\begin{array}{l}\text { Task } \\
4\end{array}$ & $\begin{array}{l}\text { Task } \\
5\end{array}$ & $\begin{array}{l}\text { Task } \\
6\end{array}$ & $\begin{array}{l}\text { Task } \\
7\end{array}$ \\
\hline $\begin{array}{l}\text { Pre Evaluation } \\
\text { Mean }\end{array}$ & 6.6 & 37.1 & 3.7 & 3.1 & 0 & 2.5 & 14.4 \\
\hline $\begin{array}{l}\text { Post } \\
\text { Evaluation } \\
\text { Mean }\end{array}$ & 9.9 & 65.9 & 8.1 & 8.2 & 7.4 & 28.6 & 20.7 \\
\hline
\end{tabular}

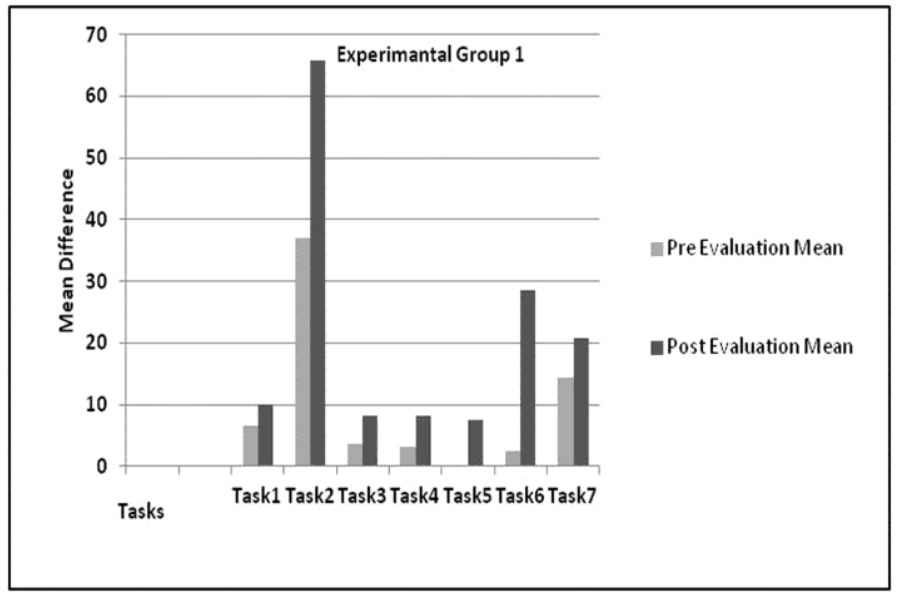

Fig. 8. Pre and post evaluation mean of experimental group 1 in all 7 tasks.

c) Pre and Post-test Mean Results of Control Group: There were selected 15 students of grade 3 and evaluating all 7 tasks of EGRA among students and the pre and post evaluation mean are shown in Table 4 and Fig. 10. d) Comparison of Mean Differences of Pre and PostTest Evaluation of All Three Groups: The results of Mean difference of pre and post-evaluation of all 7 tasks among all three groups, showed that both experimental groups have higher mean dieefernces as compared to control group as shown in Table 5 and Fig. 11.

2) Measuring Satatistical Significance of Results: Results showed that both experimental groups had higher post-test means as compared to control group. Then differences of pre and post-test mean of all 7 tasks in all groups and compared among the groups were measured. Finally statistical significance $(\mathrm{p}<0.001$, Mann-Whitney) of pre and post-test mean differences was measured. The term "YES" is used when results were significant $(p<0.001)$ and "NO" was used when results were not significant $(\mathrm{p}<0.001)$. Mean differences and their statistical significance are given below.

a) Comparesion of Mean Diffrence and Statistical Significance of Experimental Group 1 and Control Group: The result of Mean difference of Pre and Post-Evaluation of all 7 tasks and their Statistically Significant values are shown in Table 6.

b) Comapresion of Mean Diffrence and Statistical Significance of Experimental Group 2 and Control Group: The result of Mean difference of Pre and Post-Evaluation of all 7 tasks and their Statistical Significant values are shown in Table 7.

c) Comapresion of Mean Diffrence and Statistical Significance of Experimental Group 1 and Experimental Group 2: The result of mean difference of Pre and PostEvaluation of all 7 tasks and their Statistical Significant values are shown in Table 8.

TABLE III. PRE AND Post Evaluation MEAN Of EXPERIMENTAL GROUP 2 IN ALL 7 TASKS

\begin{tabular}{|c|c|c|c|c|c|c|c|}
\hline \multirow{2}{*}{$\begin{array}{l}\text { Mean of } \\
\text { Experimental } \\
\text { Group } 2\end{array}$} & \multicolumn{7}{|c|}{ Tasks } \\
\hline & $\begin{array}{l}\text { Task } \\
1\end{array}$ & $\begin{array}{l}\text { Task } \\
2\end{array}$ & $\begin{array}{l}\text { Task } \\
3\end{array}$ & $\begin{array}{l}\text { Task } \\
4\end{array}$ & $\begin{array}{l}\text { Task } \\
5\end{array}$ & $\begin{array}{l}\text { Task } \\
6\end{array}$ & $\begin{array}{l}\text { Task } \\
7\end{array}$ \\
\hline $\begin{array}{l}\text { Pre Evaluation } \\
\text { Mean }\end{array}$ & 7.4 & 21.4 & 0.7 & 1.3 & 0 & 1.6 & 3.8 \\
\hline $\begin{array}{l}\text { Post } \\
\text { Evaluation } \\
\text { Mean }\end{array}$ & 10 & 68.2 & 9.1 & 8.8 & 7.9 & 31 & 22.4 \\
\hline
\end{tabular}

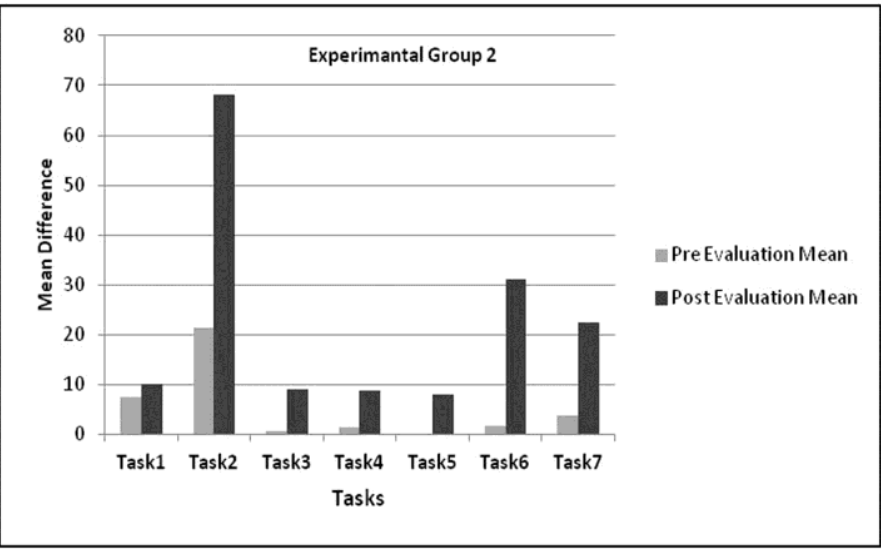

Fig. 9. Pre and post evaluation mean of experimental group 2 in all 7 task.s. 
TABLE IV. PRE ANd Post EVAluation MEAN OF CONTROL Group IN ALL 7 TASKS

\begin{tabular}{|c|c|c|c|c|c|c|c|}
\hline \multirow{2}{*}{$\begin{array}{l}\text { Mean of } \\
\text { Control } \\
\text { Group }\end{array}$} & \multicolumn{7}{|c|}{ Tasks } \\
\hline & $\begin{array}{l}\text { Task } \\
1\end{array}$ & $\begin{array}{l}\text { Task } \\
2\end{array}$ & $\begin{array}{l}\text { Task } \\
3\end{array}$ & $\begin{array}{l}\text { Task } \\
4\end{array}$ & $\begin{array}{l}\text { Task } \\
5\end{array}$ & $\begin{array}{l}\text { Task } \\
6\end{array}$ & $\begin{array}{l}\text { Task } \\
7\end{array}$ \\
\hline $\begin{array}{l}\text { Pre-evaluation } \\
\text { Mean }\end{array}$ & 6.5 & 34.4 & 3.7 & 3.6 & 0 & 2.4 & 11.8 \\
\hline $\begin{array}{l}\text { Post-valuation } \\
\text { Mean }\end{array}$ & 9.2 & 58.3 & 5.1 & 5.5 & 4.3 & 6.1 & 15.6 \\
\hline
\end{tabular}

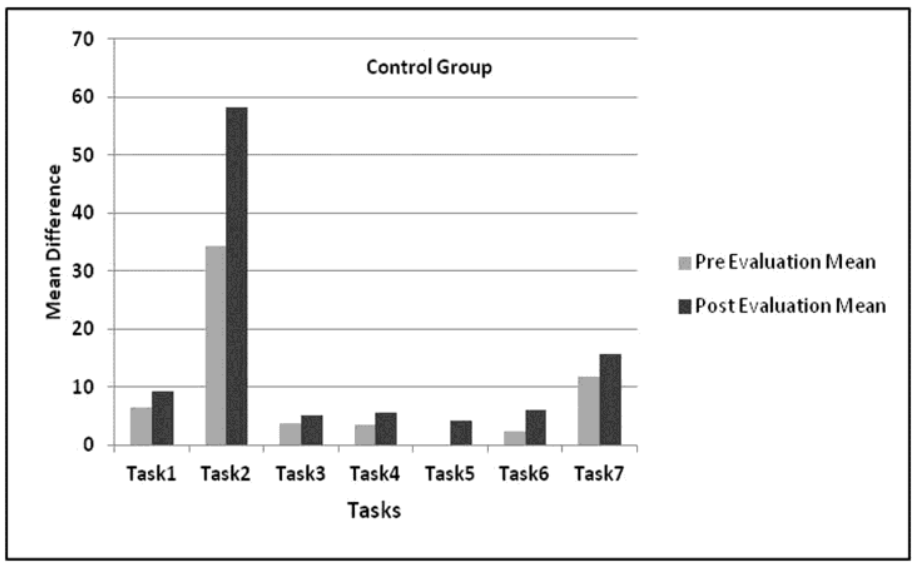

Fig. 10. Pre and post evaluation mean of control group in all 7 tasks.

TABLE V. MEAN DifFERENCE OF EXPERIMENTAL GROUPS AND CONTROL GROUP IN ALL 7 TASKS

\begin{tabular}{|c|c|c|c|c|c|c|c|}
\hline \multirow[b]{2}{*}{ Groups } & \multicolumn{7}{|c|}{ Tasks } \\
\hline & $\begin{array}{l}\text { Tas } \\
k 1\end{array}$ & $\begin{array}{l}\text { Task } \\
2\end{array}$ & $\begin{array}{l}\text { Task } \\
3\end{array}$ & $\begin{array}{l}\text { Task } \\
4\end{array}$ & Task & $\begin{array}{l}\text { Task } \\
6\end{array}$ & $\begin{array}{l}\text { Task } \\
7\end{array}$ \\
\hline $\begin{array}{l}\text { Experimental } \\
\text { Group } 1 \text { Mean } \\
\text { Differences }\end{array}$ & 3.3 & 28.8 & 4.4 & 5.1 & 7.4 & 26.1 & 6.3 \\
\hline $\begin{array}{l}\text { Experimental } \\
\text { Group } 2 \text { Mean } \\
\text { Differences }\end{array}$ & 2.6 & 46.8 & 8.4 & 7.5 & 7.9 & 29.4 & 18.6 \\
\hline $\begin{array}{l}\text { Control Group } \\
\text { Mean } \\
\text { Differences }\end{array}$ & 2.7 & 23.9 & 1.4 & 1.9 & 4.3 & 3.7 & 3.8 \\
\hline
\end{tabular}

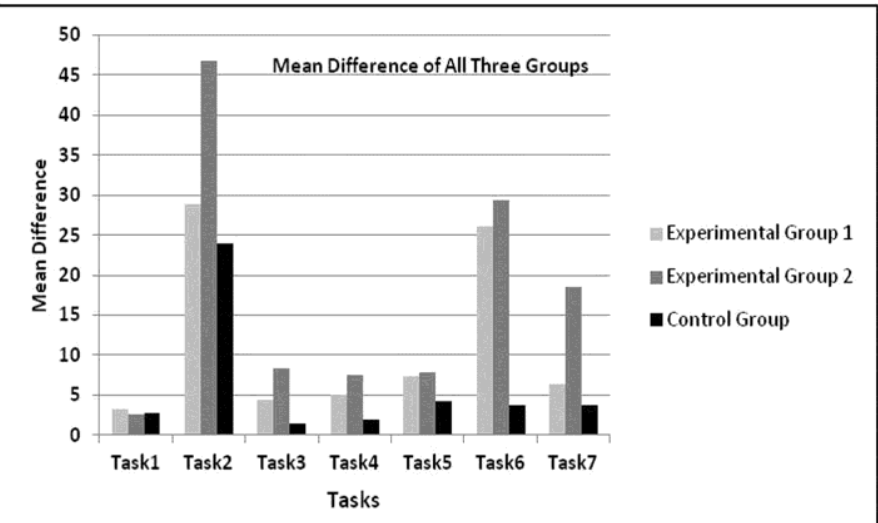

Fig. 11. Pre and post evaluation mean of control and experimental groups in all 7 tasks.
TABLE VI. MEAN DIFFERENCE OF EXPERIMENTAL GROUP 1 AND CONTROL GROUP

\begin{tabular}{|c|c|c|c|}
\hline \multirow[b]{2}{*}{ Tasks } & \multicolumn{3}{|l|}{ Groups } \\
\hline & $\begin{array}{l}\text { Experimental: } \\
\text { Group } 1 \text { Mean } \\
\text { Difference }\end{array}$ & $\begin{array}{l}\text { Control Group } \\
\text { Mean } \\
\text { Difference }\end{array}$ & $\begin{array}{l}\text { Statistical } \\
\text { Significant }\end{array}$ \\
\hline Task 1 & 3.3 & 2.7 & No \\
\hline Task 2 & 28.8 & 23.9 & No \\
\hline Task 3 & 4.4 & 1.4 & Yes \\
\hline Task 4 & 5.1 & 1.9 & Yes \\
\hline Task 5 & 7.4 & 4.3 & Yes \\
\hline Task 6 & 26.1 & 3.7 & Yes \\
\hline Task 7 & 6.3 & 3.8 & No \\
\hline $\begin{array}{l}\text { Combined } \\
\text { Result of } \\
\text { All Tasks }\end{array}$ & 81.4 & 41.7 & Yes \\
\hline
\end{tabular}

TABLE VII. MEAN DIFFERENCE OF EXPERIMENTAL GROUP 2 AND CONTROL GROUP

\begin{tabular}{|l|l|l|l|}
\hline \multirow{2}{*}{ Tasks } & \multicolumn{3}{|l|}{ Groups } \\
\cline { 2 - 4 } & $\begin{array}{l}\text { Experimental: } \\
\text { Group 2 Mean } \\
\text { Difference }\end{array}$ & $\begin{array}{l}\text { Control Group } \\
\text { Mean } \\
\text { Difference }\end{array}$ & $\begin{array}{l}\text { Statistical } \\
\text { Significant }\end{array}$ \\
\hline Task 1 & 2.6 & 2.7 & No \\
\hline Task 2 & 46.8 & 23.9 & Yes \\
\hline Task 3 & 8.4 & 1.4 & Yes \\
\hline Task 4 & 7.5 & 1.9 & Yes \\
\hline Task 5 & 7.9 & 4.3 & Yes \\
\hline Task 6 & 29.4 & 3.7 & Yes \\
\hline Task 7 & 18.6 & 3.8 & Yes \\
\hline $\begin{array}{l}\text { Combined } \\
\text { Result of } \\
\text { All Tasks }\end{array}$ & 121.3 & 41.7 & Yes \\
\hline
\end{tabular}

TABLE VIII. MEAN DIFFERENCE OF EXPERIMENTAL GROUP 1 AND EXPERIMENTAL GROUP 2

\begin{tabular}{|c|c|c|c|}
\hline \multirow[b]{2}{*}{ Tasks } & \multicolumn{3}{|l|}{ Groups } \\
\hline & $\begin{array}{l}\text { Experimental: } \\
\text { Group 1 Mean } \\
\text { Difference }\end{array}$ & $\begin{array}{l}\text { Experimental: } \\
\text { Group } 2 \text { Mean } \\
\text { Difference }\end{array}$ & $\begin{array}{l}\text { Statistical } \\
\text { Significant }\end{array}$ \\
\hline Task 1 & 3.3 & 2.6 & No \\
\hline Task 2 & 28.8 & 46.8 & Yes \\
\hline Task 3 & 4.4 & 8.4 & Yes \\
\hline Task 4 & 5.1 & 7.5 & Yes \\
\hline Task 5 & 7.4 & 7.9 & No \\
\hline Task 6 & 26.1 & 29.4 & No \\
\hline Task 7 & 6.3 & 18.6 & Yes \\
\hline $\begin{array}{l}\text { Combined } \\
\text { Result of } \\
\text { All Tasks }\end{array}$ & 81.4 & 121.3 & Yes \\
\hline
\end{tabular}

\section{CONCLUSION}

The aim of this research was to measure the students learning outcomes through English Learning Mobile Application by improving English Listening Comprehension. For measuring the improvements of English learning 
outcomes in students through English learning mobile application, a prototype was developed which was assessed by the students.

From the literature review it was found that English learning mobile application is helpful tool as it not only improve English learning but also measure the learning of the students. The developed prototype was evaluated on the basis of EGRA test which is based on knowledge and comprehension layers of Cognitive domain of Bloom's taxonomy. From the overall evaluations it is concluded that students learning outcomes in terms of remembering object names, reading text/lessons, spellings and knowledge of grammar improved by using the English learning mobile application. The results were compared among three groups which showed that designed prototype has statistically significant ( $\mathrm{p}<0.001$, Mann-Whitney) impact on both experimental groups as compared to control group. Further it is concluded that students were motivated, happy and excited to be having learning through M-learning application, so that they can learn anywhere where they want.

The evaluation results showed that developed application was helpful for students who live in rural areas where they face problems doing their homework, since their relatives are not capable to teach them as accordingly.

\section{RESEARCH LIMITATIONS}

This study is limited to the identification of the problem scenario of English curriculum comprehension in rural students which becomes an obstacle in their learning. This dissertation is confined to English curriculum learning by improving Listening comprehension. The M-Learning application developed in this research is auditory and limited to implementation of English curriculum of grades 1, 2 and 3 of Sindh Textbook Board, which will enable students to hear and comprehend well. For assessment and evaluation, students of grade 3 were selected with age from 10 to 14 years. The EGRA test based on knowledge and comprehension layers of Cognitive domain of Bloom's Taxonomy question types selected for assessment and evaluation.

\section{FUTURE RECOMMENDATION}

In this study various possibilities for future work are recommended.

1) The Prototype can be Enhanced for Secondary Grades: The prototype has been developed for elementary level students of grade 1, 2 and 3 and it especially embeded their own English crriculum. Results of evaluation showed heigher mean difference values as well as statically significant for both experimental groups as comapred to control group, therefore it can also be extended for secondary grade students which embeds their own curriculum of college.

2) The Prototype can be Extended for Other Courses: The prototype has emboided English curriculum of Sindh Textbook Board and results of evaluation showed improvement in English crriculum learning. So it can also be extended for other curricular subjects for improvement of students learning outcomes.
3) The Prototype can be Evaluated on Other Layers of Cognitive Domain: The prototype has been dveloped and evaluated on the basis of Knowledge and Comprehension layers, therefore it can be evaluated on other layers of cognitive domain to identify that how students will response to question types of other layers.

\section{ACKNOWLEDGEMENT}

Utmost thanks to the headmasters Mr. Nazar Ali Nizamani and Mr. Abdul Karim Sirewal, and the students of Govt. Boys Primary School, and also to the head and students of DarulElomia-Latifia, Dist. Sanghar, Taluka Sinjhoro, Sindh, Pakistan for their participation.

\section{REFERENCES}

[1] Aziz. A.A, Umar. M, Dilshad. F, Mustafa. M, "Learning difficulties and strategies of students at higher secondary schools in punjab," Journal of Policy Research, vol. 1, pp. 55-61, 2015.

[2] Tariq. A. R, Bilal. H. A, Sandhu. M. A, Iqbal. A. \& Hayat. U, "Difficulties in learning english as second language in rural areas of pakistan”, Academic Research Internationals, vol. 4, pp .24-34, 2013.

[3] Salahuddin. A. N. M, Khan. M. M. R \& Rahman. M. A, "Challenges of implementing english curriculum at rural primary schools of Bangladesh", The International Journal of Social Sciences, vol. 7, pp. 34-51, 2013.

[4] Kazmi. S. L, "A study of social factors affecting english learning at elementary level in rural areas of mianwali", M.A Thesis, Allama Iqbal open University.

[5] Neha D, "An analysis of factors affecting teaching and learning of english language in rural and semi-urban colleges of India", Global Journal For Research Analysis, vol. 4, pp 2277-8160, 2015.

[6] Kam, M., Kumar, A., Jain, S., Mathur, A. \& Canny, J, “Improving literacy in rural india: cellphone games in an after-school program" IEEE, International Conference on Information and Communication Technologies and Development, pp. 139-149, April, 2009.

[7] Weng. H.T \& Chen. J.Y, "Students' perceptions towards the use of smart phone applications for english learning", International Journal of Educational, vol. 5, pp. 1-10, 2015.

[8] Goundar.S, "What is the potential impact of using mobile devices in education", In Proceedings of SIG GlobDev Fourth Annual Workshop.

[9] Valk. J. H, Rashid. A. T, \& Elder. L. "Using mobile phones to improve educational outcomes: An analysis of evidence from Asia", The International Review of Research in Open and Distributed Learning, vol. 1, pp 117-140, 2010.

[10] Hsu. C. K., Hwang. G. J, Chang Y. T \& Chang. C. K, “ Effects of video caption modes on english listening comprehension and vocabulary acquisition using handheld devices", Educational Technology \& Society, vol. 16, pp. 403-414, 2013.

[11] I Andersen "A review of 7 complete english course apps", B.A Thesis in Spanish language Teaching, 2013.

[12] ANDERGRIFT. L \& BAKER. S, " Learner variables in second language listening comprehension: an exploratory path analysis", Language Learning a Journal of Research and Language Learning, vol. 65 , pp. $390-416,2015$.

[13] Gilakjani, A. P., \& Ahmadi, M. R. "A study of factors affecting efl learners' english listening comprehension and the strategies for improvement", Journal of Language Teaching and Research, vol. 2, pp. 977-988, 2011.

[14] Luo. C, "An action research plan for developing and implementing the students' listening comprehension skills", English Language Teaching, vol. 1, pp.25, 2008.

[15] Vandergrift. L, "Facilitating second language listening comprehension: acquiring successful strategies" ELT journal, vol.53, pp.168-176, 1999.

[16] Pearson. D. P \& Fielding. L, "Instructional implications of listening comprehension research", Reading Education Report No. 39, University of Illinois at Urbana-Champaign, 1983. 
[17] Lee. S. M, "User experience of a mobile speaking application with automatic speech recognition for EFL learning", British Journal of Educational Technology, 2015.

[18] Hwang. W. Y, Shih. T. K., Ma. Z. H, Shadiev. R \& Chen. S. Y," Computer assisted language learning, evaluating listening and speaking skills in a mobile game-based learning environment with situational contexts", [ahead-of-print], 1-19, 2015.

[19] Hwang. W. Y, Shih. T. K., Ma. Z. H. Shadiev. R, \& Chen. S. Y, "Effects of using mobile devices on english listening diversity and speaking for efl elementary students", Australasian Journal of Educational Technology, vol. $30,2014$.

[20] Agusalim. I. D, Assidiqi. M. H, Kom. S \& Muhammad. A. F, "Developing mobile application of interactive english pronunciation training to improve efl students' pronunciation skill", Journal of Education and Practice, vol. 5, pp.135-139, 2014.

[21] Suhartono. D, Calvin, Yustina. M, Kurniawati. S, Soeparno. H, Purnomo. F, "Implementation of voice recognition technology on English learning application by self-learning based on android device", 2013.
[22] Li. Z, \& Hegelheimer. V, "Mobile-assisted grammar exercises: effects on self-editing in 12 writing", Language Learning \& Technology, vol. 17, pp.135-156, 2013.

[23] Ally. M, Mcgreal. R., Schafer. S, Tin. T., \& Cheung. B, ” Use of mobile learning technology to train ESL adults", [Digests $6^{\text {th }}$ International Conference on Mobile Learning, Melbourne, 2007].

[24] Hsu, C. K., Learning motivation and adaptive video caption filtering for EFL learners using handheld devices, vol.27, pp. 84-103, 2015.

[25] Bloom.B.S, Engelhart. M.D., Furst. E.J, Hill. W.H., Krathwohl. D.R, "Taxonomy of educational objectives, handbook i", The Cognitive Domain. New York: David McKay Co Inc, 1956.

[26] Davidson. M and Hobbs. Jenny, "Delivering reading intervention to the poorest children, The case of Liberia and EGRA-Plus, a primary grade reading assessment and intervision", International Journals of Educational Development, vol.33, pp.283-293, 2013.

[27] Piper. B and korda.M," EGRA Plus: Liberia Program evaluation report", RTI International, 2011.

[28] Toolkit, Early Grade Reading Assessment,” 2009. 